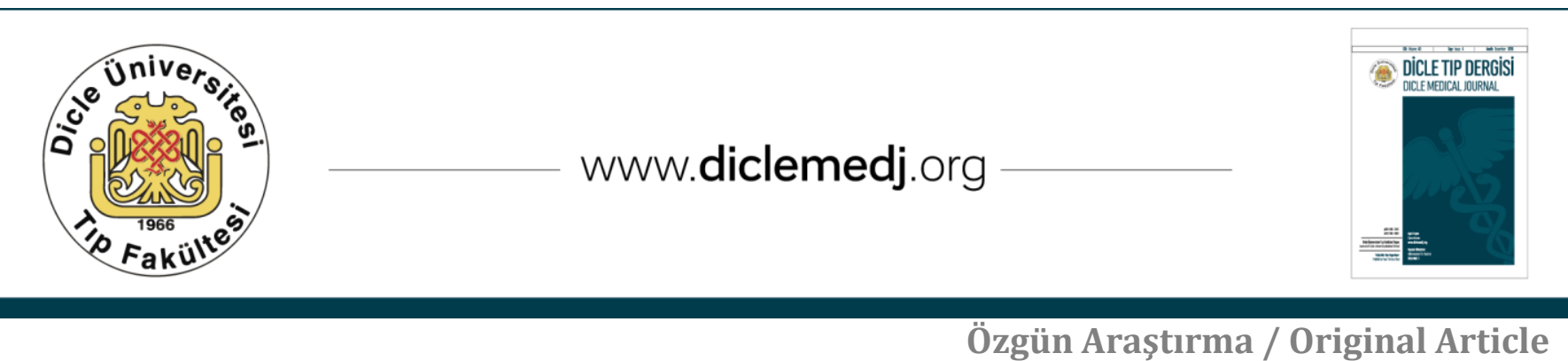

\title{
Bireylerin Tıbbi Hatalarla İlgili Görüş ve Deneyimleri
}

\author{
Ayşe Yücesan'1, Sultan Ayaz Alkaya² \\ 1 Hacettepe Üniversitesi Hemşirelik Fakültesi, Ankara, Türkiye \\ 2 Gazi Üniversitesi Sağlık Bilimleri Fakültesi Hemşirelik Bölümü, Ankara, Türkiye \\ Geliş: 10.08.2016; Revizyon: 13.01.2017; Kabul Tarihi: 18.01.2017
}

\section{Özet}

Giriş: Bu araştırma, bireylerin tıbbi hatalarla ilgili görüş ve deneyimlerini belirlemek amacıyla yapılmıştır.

Yöntemler: Tanımlayıcı tipteki araştırmanın evrenini Ankara'nın farklı iki bölgesinde yer alan iki halk eğitim merkezindeki kursiyerler oluşturmuştur. Araştırmada örneklem seçilmemiş, çalışmaya katılmayı kabul eden 567 kişi örnekleme dahil edilmiştir. Verilerin toplanmasında anket formu kullanılmıştır. Verilerin analizinde sayı, yüzdelik dağılımları ve ki-kare testi kullanılmıştır.

Bulgular: Bireylerin \% 46,7'si kendisi veya yakınlarının tıbbi hataya maruz kaldığını belirtti. Katılımcıların \% 69,3'ü hasta ve sağlık personelleri arasındaki iletişim eksikliğinin tıbbi hatalara neden olduğunu, \% 64,2'si tıbbi hata yapanların dava edilmesi gerektiğini, \% 83,1'i tıbbi hataların önlenebileceğini ifade etti. En fazla karşılaşılan tıbbi hata türünün ilaç uygulama hatası (\% 34,3) olduğu belirlenmiştir. Bireylerin \% 46,7'si kendilerinin veya yakınlarının tıbbi hata ile karşılaştığını, \%78,5’i kendileri veya yakınlarının tıbbi hata sonucunda zarar gördüğünü belirtmiştir.

Sonuç: Bireylerin yaklaşık yarısının kendisi veya yakınlarının tıbbi hataya maruz kaldığı ve büyük çoğunluğunun tıbbi hataların önlenebileceği görüşünde olduğu belirlenmiştir. Tıbbi hataların önlenmesi için bireylerin tıbbi hatalar ve korunma ile ilgili bilgilendirilmeleri, sorumluluk almaları için teşvik edilmeleri, deneyimlerinden yararlanılması ve alınacak önlemlere dahil edilmeleri önerilmektedir.

Anahtar kelimeler: Tıbbi hata, hasta güvenliği

DOI: $10.5798 /$ dicletip. 298577

Yazışma Adresi / Correspondence: Sultan Ayaz Alkaya, Gazi Üniversitesi Sağlı Bilimleri Fakültesi Hemşirelik Bölümü Beşevler, Ankara, Türkiye

Email:ayaz_sultan@hotmail.com 


\title{
Opinions and experiences of individuals regarding medical errors
}

\begin{abstract}
Aim: This research was conducted to describe opinions and determine experiences of individuals regarding medical errors.

Methods: Population of this descriptive study consisted of trainees who attended the course in two public education centers in two different regions of Ankara. No sample was selected, 567 trainees who accepted to participate in the study constituted the sample. Data were collected by using a questionnaire. Frequencies, percentage distribution and chi-square tests were used in the evaluation.

Results: The respondents of $46.7 \%$ stated that they or their relatives are exposed to medical errors. Of the subjects, $69.3 \%$ stated that lack of communication between the patient and the medical staff is the cause of medical errors, $64.2 \%$ reported that those who make errors should be sued, $83.1 \%$ said medical errors were preventable. Most of encountered types of medical errors were medication errors (34.3\%). Most (83.1\%) of the subjects stated that medical errors were preventable. A medical error had been experienced by the subject or a relative in $46.7 \%$. The percentage of subjects who felt they or their relatives had been harmed by the medical error was 78.5\%.

Conclusions: It was concluded that approximately half of individuals or relatives exposed to medical errors and most of the subjects thought that medical errors were preventable. To prevent medical error, informing individuals about medical errors and prevention, encouraging to take responsibility, using experiences of individuals and including in the measures to be taken is recommended.
\end{abstract}

Keywords: Medical error; patient safety.

\section{GíRIS}

Tıbbi hatalar, sağlık hizmetleri sırasında bir aksamanın neden olduğu, kasıtsız ve beklenmeyen sonuçlardır. Son yıllarda kronik hastalıkların artması, sağlık çalışanlarının deneyim eksikliği, bakım hizmetlerinin karmaşık hale gelmesi, sağlı çalışanları ve hastalar arasındaki iletişim eksikliği nedeniyle sağllk hizmetlerinin sunumu sirasında hata ve istenmeyen olayların meydana gelme riski artmaktadır [1,2]. Ülke, bölge veya kurum fark etmeksizin tıbbi hatalar hemen her yerde meydana gelmekte olup, bireylerin tıbbi hata ile karşılaşma durumları \%10-42 arasında değişmektedir [3-7].

Tıbbi hatalar, kişilerden kaynaklanıyor gibi görünse de temelde kurumdaki çalışan, araçgereç, prosedür ve iletişim eksikliğinden veya e-reçete, elektronik hasta kaydı, bilgisayar destekli laboratuvar sistemi gibi teknolojilerin yeterince kullanılmamasından dolayı meydana gelmektedir $[3,8,9]$. Meydana gelen hatalar, bireylerin hastanede kalış sürelerini uzatmakta, ciddi yaralanmalara, sakatlığa hatta ölüme neden olabilmektedir $[6,7,10-12]$. Literatürde çoğunluğunun önlenebilir olduğu belirtilen tıbbi hatalar nedeniyle ortaya çıkan ek maliyetin yıllık 8.8-19.5 milyon dolar arasında olduğu tahmin edilmektedir $[11,13,14]$.

Tıbbi hataların önlenmesi için sağlık sistemi, kurum, çalışan ve hasta/sağlıklı bireyleri de ilgilendiren önlemlerin alınması gerekmektedir. $\mathrm{Bu}$ bağlamda izlenecek yeni yollar ve sistem değişikliklerinin belirlenmesinde tıbbi hatalarm ve nedenlerinin öğrenilmesinin yol gösterici olacağı belirtilmektedir [15,16]. Tibbi hataların ve nedenlerinin belirlenmesindeki engellerden biri sağlık çalışanlarının cezalandırılma korkusu ve hukuksal yaptırımlardan dolayı, hataları raporlamaktan ve hastalara açıklamaktan kaçınmalarıdır [17-19]. Öte yandan önemli bir veri kaynağı olan, hasta/sağlıklı bireylerin deneyimlerine ve görüşlerine de yeterince önem verilmemektedir. Türkiye'de tıbbi hatalarla 
ilgili yapılan çalışmalar son zamanlarda artış göstermekle birlikte, bu çalışmalar daha çok sağlık çalışanlarının bu konudaki bilgi, görüş, tutum ve deneyimlerini belirlemeye yöneliktir. Günümüzde sağlık ekibinin bir parçası olan bireylerin, tıbbi hatalarla ilgili görüş ve deneyimlerinin belirlenmesinin, tıbbi hataların önlenmesi için gerekli önlemlerin alınması ve uygulanmasında yol gösterici olacağı düşünülmektedir.

Araştırma, bireylerin tıbbi hatalarla ilgili görüş ve deneyimlerini belirlemek amaciyla yapılmıştır. $\mathrm{Bu}$ amaç doğrultusunda aşağıdaki sorulara yanıt aranmıştır:

1. Bireylerin hasta güvenliğine ilişkin görüşleri nelerdir?

2. Bireylerin tıbbi hatalarla ilgili deneyimleri nelerdir?

\section{YÖNTEMLER}

Araştırma tanımlayıcı tipte yapılmıştır. Araştırmanın evrenini Mamak Halk Eğitim Merkezi ve Başkent Halk Eğitim Merkezi'nde çeşitli kurslara devam eden bireyler oluşturmuştur. İki farklı halk eğitim merkezinin seçilmesinin nedeni bölgelerin sosyo-ekonomik ve kültürel özellikler açısından farklılık göstermesidir. Bireyler, halk eğitim merkezlerinin bulunduğu bölgede ikamet etmekte, bulunduğu bölgedeki bireylerle benzer sosyo-ekonomik ve kültürel özellikleri taşımaktadırlar.

Araştırmanın evreni halk eğitim merkezlerinin kursiyer kayıt sistemlerindeki veri eksikliği nedeniyle kesin olarak belirlenememiștir. $\mathrm{Bu}$ nedenle araştırmanın örneklemini belirlemede evrenin bilinmediği durumlarda örnekleme alınacak birey sayısını saptamak için kullanılan formül uygulanmış ve örneklem sayısı 263 olarak belirlenmiştir. Araştırmanın güvenilirliğini artırmak amacıyla çalışmaya katılmayı kabul eden ve araştırmaya dahil edilme kriterlerine uyan 567 kişi (Mamak Halk Eğitim Merkezi=408, Başkent Halk Eğitim Merkezi=159 olmak üzere) örnekleme alınmıştır. Araștırmaya dahil edilme kriterleri; 18 yaş üzeri olma, kurslara devam etme, okuryazar olma, algılama güçlüğü ve zihinsel engeli olmamadır.

Veriler araștırmacı tarafından literatür bilgileri [3,8,9,10-15] doğrultusunda hazırlanan anket formu ile toplanmıştır. Anket formu 3 bölümden oluşmaktadır. Birinci bölümde araştırmaya katılan bireylerin yaş, cinsiyet, öğrenim durumu, medeni durum, en uzun süre yaşadıkları yer gibi sosyo-demografik özelliklerini, ikinci bölümde tıbbi hatalarla ilgili görüşlerini, üçüncü bölümde tıbbi hatalarla ilgili deneyimlerini belirlemeye yönelik açık ve kapalı uçlu 34 soru yer almaktadır. Açık uçlu soru örnekleri: "Sizce tıbbi hatalar nasıl önlenebilir?", "Hastalar kendilerini tıbbi hatalardan koruyabilmek için neler yapmalıdır?".

Veri toplamaya başlamadan önce bireylerin tıbbi hata kavramı ve türlerini bilmedikleri varsayılmıştır. Bu nedenle ortak dil oluşturmak amaciyla anket formu uygulanmadan önce araştırmacı tarafından tıbbi hata kavramı ve tıbbi hata türleri ile ilgili bilgilendirme yapılmıştır. Bilgilendirme 8-10 kişilik gruplar şeklinde gerçekleştirilmiş, bireylere konuyla ilgili bilgilerin yer aldığı broşür dağıtılmıştır. Bilgilendirme sonrasında bireyler araştırmacı gözetiminde anket formundaki soruları yanıtlamışlardır. Anket formunun uygulaması 20-25 dakika sürmüştür.

Araştırmada elde edilen veriler SPSS 15.0 paket programı ile değerlendirilmiştir. Verilerin değerlendirilmesinde sayı, yüzdelik dağılımları ve ki-kare testi kullanılmıștır. Araştırmada bireylerin sosyo-demografik özellikleri, hasta güvenliğine ilişkin görüşleri ve deneyimleri sayı ve yüzde olarak verilmiştir. Kategorik karşılaștırmalar ki-kare testi ile incelenmiștir. Analizde anlamlılık düzeyi $\mathrm{p}<0.05$ olarak alınmiştır.

Araştırmanın etik açıdan uygunluğunun değerlendirilmesi amacıyla Ankara Üniversitesi Tıp Fakültesi Klinik Araştırmalar Etik 
Kurulu'dan etik kurul onayı alınmıştır. Araștırma öncesinde, uygulama yapılacak halk eğitim merkezlerinin bağlı olduğu Ankara İl Milli Eğitim Müdürlügü'nden yazılı izin alınmıștır. Araștırmaya katılan bireylere bilgilendirilmiş onam formu okunmuş, sözel ve yazılı izinleri alınmıştır.

Araştırmanın bazı sınırlılıkları bulunmaktadır. Araştırmaya her iki halk eğitim merkezinden de eşit sayıda bireyin dahil edilmesi planlanmış ancak Başkent Halk Eğitim Merkezi'ndeki bireylerin çalışmaya katılmayı kabul etmemesi ve merkez binada kursa devam eden birey sayısının azlığı nedenleriyle eșit sayıda birey örnekleme alınamamıștır.

\section{BULGULAR}

Bireylerin \%17,0'ının 18-24 yaş, \%34,9'unun 25-34 yaş, \%30,7'sinin 35-44 yaș, \%17,5'inin 45 ve üzeri yaş grubunda olduğu, \%80,1'inin kadın olduğu, \%38,4'ünün ilköğretim mezunu, \%33,2'sinin lise mezunu, \%28,3'ünün üniversitesi ve üzeri mezunu olduğu, \%62,8'inin evli, \%38,2'sinin bekâr olduğu, $\% 73,7$ 'sinin en uzun süre kentsel alanda, \%26,3'ünün kırsal alanda yaşadığı; \%91,9'unun sosyal güvencesinin olduğu, \%19,4'ünün kendisinde, \%36,0'ının ailesinde kronik hastalık olduğu belirlenmiştir.

Tablo 1: Bireylerin tıbbi hataların nedenleri ile ilgili görüșleri ( $n=567)$

\begin{tabular}{|c|c|c|}
\hline Tıbbi hataların meydana gelme nedenleri* & Sayl & $\%$ \\
\hline Hasta ve sağlık personelleri arasında iletişim eksikliği & 393 & 69,3 \\
\hline Doktorların hastalara yeterince zaman ayırmaması & 376 & 66,3 \\
\hline Sağlık personelinin uzun çalışma saatleri nedeniyle yorgunluk ve stres yaşaması & 338 & 59,6 \\
\hline Hemşire sayısının yetersiz olması & 328 & 57,8 \\
\hline Doktorların el yazılarının okunaklı olmaması & 278 & 49,0 \\
\hline Hasta/sağlıklı bireylerin hasta güvenliği ile ilgili bilgi eksikliğinin olması & 274 & 48,3 \\
\hline Sağlık hizmetlerinin karmaşık bir yapıda olması & 193 & 34,0 \\
\hline Mesleki eğitimin yetersiz olması & 185 & 32,6 \\
\hline \multicolumn{3}{|l|}{ Tıbbi hata meydana geldiğinde yapılacak uygulamalar* } \\
\hline Hata yapanlar dava edilmeli & 364 & 64,2 \\
\hline Yapılan hatalar hastaya açıklanmalı & 339 & 59,8 \\
\hline Hata yapan kişi ya da kişiler iş yerinden uzaklaştırılmalı & 292 & 51,5 \\
\hline Hastadan özür dilenmeli & 200 & 35,3 \\
\hline Hasta zarar görmediyse hiçbir şey yapılmamalı & 105 & 18,5 \\
\hline Kişi cezalandırılmadan sadece olay raporlanmalı & 30 & 5,3 \\
\hline
\end{tabular}

* Birden fazla seçenek işaretlenmiștir.

Bireylerin \%69,3'ü hasta ve sağlık personelleri arasındaki iletișim eksikliğinin, \%66,3'ü doktorların hastalara yeterince zaman ayırmamasının, \%59,6'sı sağlık personelinin uzun çalışma saatleri nedeniyle yorgunluk ve stres yaşamasının,\%57,8'i hemşire sayısının yetersiz olmasının, \%49'u doktorların el yazılarının okunaklı olmamasının, \%48,3'ü hasta/sağlıklı bireylerin hasta güvenliği ile ilgili bilgi eksikliği olmasının tıbbi hatalara neden olduğunu belirtmişlerdir (Tablo 1).

Bireylerin \%64,2'si herhangi bir tıbbi hata meydana geldiğinde hata yapanların dava edilmesi, $\% 59,8$ 'i yapılan hataların hastaya açıklanması, \%51,5'i hata yapan kişi ya da kişiler iş yerinden uzaklaştırılması, \%35,3'ü 
hastadan özür dilenmesi, \%18,5'i hasta zarar görmediyse hiçbir şey yapılmaması, \%5,3'ü kişi cezalandırılmadan sadece olayın raporlanması gerektiğini belirtmiştir (Tablo 1).

Bireylerin \%83,1'i tıbbi hataların önlenebilir olduğunu, tıbbi hataların önlenebilmesi için $\% 28,5$ 'i hasta güvenliği ile ilgili düzenli eğitimler yapılmasını, \%17,6'sı hasta ile sağlık çalışanları

arasındaki

iletişimin geliştirilmesinin etkili olabileceğini ifade etmiştir. Bireylerin \%26,2'si hasta güvenliği ile ilgili bilgi sahibi olmaları ve \%60'ı kendilerine yapılan girişim ve işlemleri sorgulamaları durumunda hastaların kendilerini tıbbi hatalardan koruyabileceğini belirtmiştir (Tablo 2).

Tablo 2: Bireylerin Tıbbi Hatalarla İlgili Görüșleri (n=567)

\begin{tabular}{|c|c|c|}
\hline Görüşler & Sayı & $\%$ \\
\hline \multicolumn{3}{|l|}{ Tıbbi hataları önlenebilir bulma durumu } \\
\hline Önlenebilir bulan & 471 & 83,1 \\
\hline Önlenebilir bulmayan & 36 & 6,3 \\
\hline Bilmeyen & 60 & 10,6 \\
\hline \multicolumn{3}{|l|}{ Tıbbi hataların önlenmesi için yapılması gerekenler $(n=471)^{*}$} \\
\hline Hasta güvenliği ile ilgili düzenli eğitimler yapılması & 134 & 28,5 \\
\hline Hasta ve sağlık çalışanları arasındaki iletişimin geliştirilmesi & 83 & 17,6 \\
\hline Sağlık ekibi üyelerinin görevlerini eksiksiz yerine getirmesi & 73 & 15,5 \\
\hline Yeterli sayıda sağlık personelinin istihdam edilmesi & 38 & 8,1 \\
\hline Düzenli kontrol ve denetim yapılması & 36 & 7,6 \\
\hline Hata yapanların cezalandırılması & 22 & 4,7 \\
\hline Mesleki eğitimde hasta güvenliği ile ilgili konulara yer verilmesi & 16 & 3,4 \\
\hline Çalışma saatlerinin azaltılması & 15 & 3,2 \\
\hline Hasta güvenliği ile ilgili sağlık politikalarının geliştirilmesi & 11 & 2,3 \\
\hline \multicolumn{3}{|l|}{ Hastaların tıbbi hatalardan kendilerini koruyabilme durumu } \\
\hline Koruyabilir & 340 & 60,0 \\
\hline Koruyamaz & 141 & 24,9 \\
\hline Bilmiyor & 86 & 15,2 \\
\hline \multirow{2}{*}{\multicolumn{3}{|c|}{$\begin{array}{l}\text { Hastaların tıbbi hatalardan kendilerini korumak için yapması } \\
\text { gerekenler }(n=339)\end{array}$}} \\
\hline & & \\
\hline Hasta güvenliği ile ilgili bilgi sahibi olma & 89 & 26,2 \\
\hline Kendilerine yapılan girișim ve işlemleri sorgulama & 88 & 26,0 \\
\hline Sağlık çalışanlarına tıbbi geçmişleriyle ilgili doğru bilgi verme & 43 & 12,7 \\
\hline Tedavi ve hastalıkları hakkında bilgi sahibi olma & 36 & 10,6 \\
\hline Hasta haklarını bilme & 25 & 7,4 \\
\hline Hata yapanların cezalandırılması için girişimde bulunma & 16 & 4,7 \\
\hline
\end{tabular}

* Birden fazla seçenek işaretlenmiştir. 
Bireylerin \%46,7'si kendisi veya yakınlarının sonucunda kendilerinin veya yakınlarının tıbbi hataya maruz kaldığını belirtmiştir. En herhangi bir şey yapmadıklarını belirtmişlerdir. fazla karşılaşılan tıbbi hata türleri ilaç Bireylerin \%78,5'i kendileri veya yakınlarının uygulama hatası $(\% 34,3)$, hastane enfeksiyonu tıbbi hata sonucunda zarar gördügünü; hata $(\% 30,6)$ ve yanlış tanı $(\% 28,3)$ olarak sonucunda en fazla: ek veya uzun süreli tedavi belirlenmiștir. Bireylerin \%60,0'ı yapılan tıbbi $(\% 64,4)$, şiddetli ağrı $(\% 38,5)$ ve psikolojik hata ile ilgili kendilerinin veya yakınlarının sorunlar (\%37) yaşandığını ifade etmişlerdir bilgilendirilmediklerini, \%66,8'i tıbbi hata (Tablo 3).

Tablo 3: Bireylerin veya Yakınlarının Tıbbi Hata Deneyimleri $(n=567)$

\begin{tabular}{|c|c|c|}
\hline Deneyimler & Sayı & $\%$ \\
\hline \multicolumn{3}{|l|}{ Tibbi hataya maruz kalma } \\
\hline Maruz kalan & 265 & 46,7 \\
\hline Maruz kalmayan & 302 & 53,3 \\
\hline \multicolumn{3}{|l|}{ Tıbbi hata $(n=265)^{*}$} \\
\hline İlaç hatası & 91 & 34,3 \\
\hline Hastane enfeksiyonu & 85 & 30,6 \\
\hline Yanlış tanı & 75 & 28,3 \\
\hline Kimlik doğrulama hatası & 66 & 24,9 \\
\hline Cerrahi işlem hatası & 50 & 18,9 \\
\hline Hasta düşmesi & 38 & 14,3 \\
\hline Basınç ülseri & 21 & 7,9 \\
\hline \multicolumn{3}{|c|}{ Tibbi hata ile ilgili bilgilendirilme $(n=265)$} \\
\hline Bilgilendirilen & 106 & 40,0 \\
\hline Bilgilendirilmeyen & 159 & 60,0 \\
\hline \multicolumn{3}{|c|}{ Tibbi hata sonucunda yapılanlar $(n=265)^{*}$} \\
\hline Hiçbir şey yapmama & 177 & 66,8 \\
\hline Hatadan sorumlu kişiyle görüşme & 74 & 27,9 \\
\hline Hastane yönetimine şikâyet etme & 55 & 20,8 \\
\hline Hukuksal yollara başvurma & 24 & 9,1 \\
\hline \multicolumn{3}{|c|}{ Tibbi hata sonucunda zarar görme $(n=265)$} \\
\hline Zarar gören & 208 & 78,5 \\
\hline Zarar görmeyen & 57 & 21,5 \\
\hline \multicolumn{3}{|c|}{ Tıbbi hata sonucunda meydana gelen zarar $(n=208)^{*}$} \\
\hline Ek veya uzun süreli tedavi & 134 & 64,4 \\
\hline Psikolojik sorunlar & 77 & 37,0 \\
\hline Şiddetli ağrı & 80 & 38,5 \\
\hline İş gücü kaybı & 33 & 15,9 \\
\hline Geçici veya kalıcı sakatlık & 30 & 14,4 \\
\hline İșe ya da okula gidememe & 23 & 11,1 \\
\hline Ölüm & 23 & 11,1 \\
\hline
\end{tabular}

*Birden fazla seçenek işaretlenmiştir. 
Tıbbi hataya maruz kalma ile cinsiyet, öğrenim durumu, medeni durum, en uzun süre yaşanılan yer arasında istatistiksel olarak anlamlı bir ilişki bulunmamakla birlikte
( $p>0.005$ ) yaş ve kronik hastalığl olma durumu arasında anlamlı bir ilişki bulunmuştur $(p<0.001)$ (Tablo 4).

Tablo 4: Bireylerin Sosyodemografik Özelliklerine Göre Tıbbi Hataya Maruz Kalmaları

\begin{tabular}{|c|c|c|c|c|c|}
\hline \multirow{2}{*}{ Sosyodemografik özellikler } & \multicolumn{2}{|c|}{ Evet } & \multicolumn{2}{|c|}{ Hayır } & \multirow[b]{2}{*}{$\mathbf{p}$} \\
\hline & Sayı & $\%$ & Sayı & $\%$ & \\
\hline \multicolumn{6}{|l|}{ Yaş } \\
\hline 18-24 yaș & 30 & 30,9 & 67 & 69,1 & \multirow{4}{*}{$<0.05$} \\
\hline $25-34$ yaș & 87 & 44,2 & 110 & 55,8 & \\
\hline 35-44 yaş & 88 & 50,6 & 86 & 49,4 & \\
\hline 45 ve üzeri yaş & 60 & 60,6 & 39 & 39,4 & \\
\hline \multicolumn{6}{|l|}{ Cinsiyet } \\
\hline Kadın & 59 & 52,2 & 54 & 47,8 & \multirow[b]{2}{*}{$>0.005$} \\
\hline Erkek & 206 & 45,4 & 248 & 54,6 & \\
\hline \multicolumn{6}{|l|}{ Öğrenim durumu } \\
\hline İlköğretim mezunu & 97 & 44,5 & 121 & 55,5 & \multirow{3}{*}{$>0.005$} \\
\hline Lise mezunu & 84 & 44,7 & 104 & 55,3 & \\
\hline Üniversite mezunu ve üstü & 84 & 52,2 & 77 & 47,8 & \\
\hline \multicolumn{6}{|l|}{ Medeni durum } \\
\hline Bekâr & 89 & 42,2 & 122 & 57,8 & \\
\hline Evli & 176 & 49,4 & 180 & 50,6 & $>0.005$ \\
\hline \multicolumn{6}{|l|}{ En uzun süre yaşanılan yer } \\
\hline Kırsal alan & 67 & 45,0 & 82 & 55,0 & \\
\hline Kentsel alan & 198 & 47,4 & 220 & 52,6 & $>0.005$ \\
\hline \multicolumn{6}{|l|}{ Kronik hastalık } \\
\hline Var & 68 & 61,8 & 42 & 38,2 & \\
\hline Yok & 197 & 43,1 & 260 & 56,9 & $<0.005$ \\
\hline
\end{tabular}

TARTIŞMA

Sağlık hizmetleriyle ilişkili tıbbi hatalar sistemle ve bireylerle ilişkili pek çok faktör nedeniyle meydana gelmektedir. Literatürde de tıbbi hataların sağlık çalışanlarının iş yükünün fazla olması, yorgunluk ve stres yaşaması, mesleki bilgi ve beceri eksikliğinin olması, çalışma saatlerinin uzun olması, doktorların hastalara yeterince vakit ayırmaması, hemşire sayısının yetersiz olması, sağlık çalışanları arasında iletişim eksikliği olması, hataları önleyici düzenlemelerin olmaması ve doktorların el yazısının okunaklı olmaması gibi nedenlerle meydana geldiği belirtilmektedir $[2,3,9,16]$. Bu çalışmada da bireylerin tıbbi hataların nedenlerine ilişkin görüşlerinin literatürle benzer olduğu görülmektedir.

Sağlık hizmeti sunumu sırasında meydana gelen tıbbi hataların büyük çoğunluğunun önlenebilir olduğu belirtilmektedir. $\mathrm{Bu}$ 
çalışmada, bireylerin çoğu hataların önlenebilir olduğu görüşündedir. Literatür incelendiğinde, Khoo ve ark. meydana gelen tıbbi hataların \%93,5'inin [4], Aljadhey ve ark. tıbbi hataların \%30'unun [10], Zandieh ve ark. \%23'ünün önlenebilir olduğunu belirlemişlerdir [14]. Bireylerin tıbbi hataların önlenebilir olduğunu düşünmelerinin, tıbbi hataların önlenmesi için alınacak önlemlerin uygulamaya geçirilmesinde sorumluluk almalarını kolaylaștıracağı düşünülmektedir.

Tıbbi hataların hastanelerde hasta güvenliğini geliştirici sistemlerin kurulması, mesleki eğitimin daha kaliteli hale getirilmesi, sağlık personeli sayısının artırılması, doktorların hastalara daha fazla zaman ayırması, sağlık çalışanlarının çalışma saatlerinin azaltılması ve hastanelerde gönüllü raporlama sistemlerinin oluşturulması gibi girişimlerle önlenmesi mümkündür $[6,15]$. Bu çalışmada da, bireyler tıbbi hataların önlenmesi için benzer önlemlerin alınması gerektiğini belirtmişlerdir. Sağlık çalışanları gibi hastaların da tıbbi hataların önlemesinde sorumlulukları bulunmaktadır. $\mathrm{Bu}$ çalışmada, bireylerin yarısından fazlası hastaların kendilerini tıbbi hatalardan koruyabileceğini belirtmişlerdir. Rathert ve ark. tarafından yapılan çalışmada ise bireyler sağlık durumları, tedavileri hakkında soru sormaları, kendilerine yapılan işlemleri takip etmeleri ve kendi bakımlarına aktif katılmalarının hataları önlemede etkili olacağını [17], Northcott ve ark.'nin çalışmasında bireyler tıbbi hataların önlenmesinde kendilerinin de sorumluluğu olduğunu belirtmiştir [15]. Severinsson ve Holm tarafindan yapılan sistematik derlemede hastaların kendi bakımlarına dahil edilmesinin tıbbi hata riskini azaltmada etkili olduğu saptanmıştır [18].

Tıbbi hata meydana geldiğinde cezai işlemlerden kaçınılması, olayın raporlanması ve hastalara açılklaması önerilmektedir [19]. Bu çalışmada bireylerin yarısından fazlası hata yapanların dava edilmesi ve yapilan hataların hastaya açıklanması, yaklaşık yarısı ise hata yapan kişi ya da kişilerin iş yerinden uzaklaştırılması gerektiğini belirtmişlerdir. Ancak sağlık çalışanları, durumun siciline işlenmesi, çalışma arkadaşları ve yönetici hemşirelerden tepki alma ve işini kaybetme gibi cezalandırıcı eylemler nedeniyle meydana gelen tıbbi hataları açıklamamaktadır [3,1921]. Bireyleri cezalandıran geleneksel tutum yerine hataların raporlanmasını ve hastalara açıklanmasını teşvik etmek önleme girișimlerinin belirlenmesinde etkili olacaktır.

Hem gelişmiş hem de gelişmekte olan ülkelerde, tıbbi hataların görülme sıklığı giderek artmaktadır $[6,10,11]$. Bu çalışmada da bireylerin yaklaşık yarısının kendisi veya yakınlarının tıbbi hataya maruz kaldığı belirlenmiştir. Tıbbi hataların ülke ya da bölge fark etmeksizin görülmesi bu konunun küresel bir sorun olduğunu ve küresel önlemler alınması gerektiğini göstermesi açısından önemlidir.

Karşılaşma yüzdeleri değişmekle birlikte en fazla karşılaşılan tıbbi hatalar ilaç uygulama hatası, hastane enfeksiyonu, hasta düşmesi ve yanlış tanı konulmasıdır $[4,7,11,13,22]$. Bu çalışmada, bireylerin veya yakınlarının en fazla karşılaştıkları tıbbi hata türlerinin ilaç uygulama hatası, hastane enfeksiyonu ve yanlış teşhis olduğu belirlenmiştir.

Meydana gelen tıbbi hata sonrası, hasta ve yakınlarının bilgilendirilme oranları kurum ve kurum çalışanlarına göre farklılık göstermektedir. Bu çalışmada, bireylerin ve yakınlarının tıbbi hata ile ilgili bilgilendirilme oranlarının düşük olduğu belirlenmiştir. Hayran tarafından yapılan çalışmada, tıbbi hataya maruz kalan bireylerin \%17'sinin bilgilendirildiği belirtilmiştir [5]. Literatürde sağlık çalışanları tıbbi hata sonucunda herhangi bir zarar gelmemişse hastaya açılkanması gerekmediğini, zarar meydana gelmiş ise açlklanabileceğini belirtmektedir $[8,9]$. Kurumsal olarak suçlama ya da cezalandırma yaklaşımı yerine hatalardan öğrenme 
yaklaşımının benimsenmesi hasta ve yakınlarının bilgilendirilmesini kolaylaştıracaktır. Hasta hakları kapsamında hastaların sağlık durumları ile ilgili bilgi alma hakkı bulunmaktadır [23]. Tıbbi hataların hastalara açılklanmasında sağlık profesyonellerinin hasta haklarını koruması ve bireyleri bilgilendirmesi beklenmektedir.

Tibbi hatalar yatış süresinde uzama, ek maliyet, ağrı, psikolojik sorunlar, geçici ya da kalıcı sakatlık, ölüm gibi sonuçlara neden olabilmektedir [4,6,7,11]. Bu çalışmada da, bireyler kendilerinde veya yakınlarında ek veya uzun süreli tedavi, psikolojik sorunlar, şiddetli ağrı, iş gücü kaybı, geçici veya kalıcı sakatlık, işe veya okula gidememe, ölüm gibi zararların meydana geldiğini ifade etmişlerdir. Sürekli bakım ve tedavi hizmeti sunan sağlık profesyonellerinin risklerin belirlenmesi, herhangi bir tıbbi hata durumunda oluşabilecek zararların erken tespiti ve önlenmesinde sorumluluk almaları gerekmektedir.

Literatürde ileri yaşta olan ve kronik hastalığ olan kişilerin daha fazla tıbbi hata deneyimledikleri belirtilmektedir $[6,10,13]$. Benzer şekilde, bu çalışmada da ileri yaşta olan, kronik hastalığı olan bireylerin daha fazla tıbbi hataya maruz kaldıkları saptanmıştır. Bu bulgu yaşlı ve kronik hastalığı olan kişilerin daha fazla hastaneye yatmaları, muayene olmaları ve çoklu ilaç kullanmalarının tıbbi hata riskini artırdığını düşündürmektedir.

Sonuç olarak, araştırmaya katılan bireyler tıbbi hataların önlenebilir olduğunu ve önlenmesinde hastaların da sorumluluk almaları gerektiğini belirtmelerine karşın bireylerin ve yakınlarının tıbbi hata ile ilgili bilgilendirilme oranlarının düşük olduğu belirlenmiştir. Bireylerin yaklaşık yarısının kendisi veya yakınlarının tıbbi hataya maruz kaldığı, en fazla karşılaşılan tıbbi hata türlerinin ilaç uygulama hatası, hastane enfeksiyonu ve yanlış tanı olduğu belirlenmiştir. Yaş ve kronik hastalığı olma değişkenlerinin tıbbi hataya maruz kalma durumunu etkilediği belirlenmiştir. Bu sonuçlar doğrultusunda; tıbbi hataların önlenmesi için bireylerin tıbbi hatalar ve korunma ile ilgili bilgilendirilmeleri, sorumluluk almaları için teşvik edilmeleri önerilmektedir. Ayrıca, tıbbi hataların hasta ve yakınlarına açılanması, sağlık sisteminde tıbbi hatalara neden olan eksikliklerin giderilmesi, tıbbi hataların ve korunma yöntemlerinin belirlenmesinde bireylerin deneyimlerinden yararlanılması faydalı olacaktır.

Çıkar Çatışması Beyanı: Yazarlar çıkar çatışması olmadığını bildirmişlerdir.

Finansal Destek: Bu çalıșma her hangi bir fon tarafından desteklenmemiştir.

Declaration of Conflicting Interests: The authors declare that they have no conflict of interest.

Financial Disclosure: No financial support was received.

\section{KAYNAKLAR}

1. Cebeci F. Hasta güvenliğinde acil hemşirelerinin rolü. Türkiye Klinikleri Hemşirelik Bilimleri Dergisi 2010; 2:57-63.

2. Shahrokhi A, Ebrahimpour F, Ghodousi A. Factors effective on medication errors: A nursing view. J Res Pharm Pract. 2013;2:18-23.

3. Alsafi E, Baharoon S, Ahmed A, et al. Physicians' knowledge and practice towards medical error reporting: a cross-sectional hospital-based study in Saudi Arabia. Eastern Mediterranean Health Journal 2015;21:655-64.

4. Khoo ME, Lee WK, Sararaks S, et al. Medical errors in primary care clinics-a cross sectional study. BMC Fam Pract. 2012;13:127.

5. Hayran M. Türkiye'de toplumun hasta güvenliği ve tıbbi uygulama hataları ile ilgili algılamalarının değerlendirilmesi. İçinde: Çakmakçı $\mathrm{M}$, Akalın $\mathrm{E}$, editörler. Hasta Güvenliği: Türkiye ve Dünya, 1. Baskı. Ankara: Türk Tabipler birliği Yayınları, 2011: 23-31.

6. Lu CY, Roughead E. Determinants of patient-reported medication errors: a comparison among seven countries. Int J Clin Pract. 2011; 65: 733-40.

7. Sakuma M, Ida H, Nakamura T, et al. Adverse drug events and medication errors in Japanese pediatric in patients: a retrospective cohort study. BMJ Qual Saf. 2014; 23:830-37. 
8. Flotta D, Rizza P, Bianco A, Pileggi C, Pavia M. Patient safety and medical errors: knowledge, attitudes and behavior among Italian hospital physicians. Int J Qual Health Care. 2012;24:258-65.

9. Yıldırım A, Aksu M, Çetin İ, Şahan A. Tokat ili merkezinde çalışan hekimlerin tıbbi uygulama hataları ile ilgili bilgi, tutum ve davranışları. Cumhuriyet Tıp Derg. 2009;31:356-66.

10. Aljadhey $H$, Mahmoud MA, Mayet A, et al. Incidence of adverse drug events in an academic hospital: a prospective cohort study. Int J Qual Health Care. 2013;25:648-55.

11. Lee J, Imanaka $Y$, Sekimoto $M$, et al. Healthcareassociated infections in acute ischaemic stroke patients from 36 Japanese hospitals: risk-adjusted economic and clinical outcomes. Int J Stroke. 2011; 6:16-24.

12. Munoz JAB, Miguez MA, Perez RMP, et al. Comparison of medication error rates and clinical effects in three medication prescription-dispensation systems. Int J Health Care Qual Assur. 2011; 24:238-48.

13. David G, Gunnarsson CL, Waters HC, et al. Economic measurement of medical errors using a hospital claims database. Value Health 2013; 16:305-10.

14. Zandieh SO, Goldmann DA, Keohane CA, et al. Risk factors in preventable adverse drug events in pediatric outpatients. J Pediatr. 2008; 152:225-31.

15. Northcott H, Vanderheyden L, Northcott J, et al. Perceptions of preventable medical errors in Alberta, Canada. Int J Qual Health Care. 2008; 20:115-22.
16. Poorolajal J, Rezaie S, Aghighi N. Barriers to medical error reporting. Int J Prev Med. 2015; 6:97-101.

17. Rathert C, Huddleston N, Pak Y. Acute care patients discuss the patient role in patient safety. Health Care Manage Rev. 2011; 36:134-44.

18. Severinsson E, Holm AL. Patients' role in their own safety-A systematic review of patient involvement in safety. Open Journal of Nursing 2015; 5:642-53.

19. Kalra J, Kalra N, Baniak N. Medical error, disclosure and patient safety: a global view of quality care. Clin Biochem. 2012; 46:1161-9.

20. Bahadori M, Ravangard R, Aghili A, et al. The factors affecting the refusal of reporting on medication errors from the nurses' viewpoints: A case study in a hospital in Iran. ISRN Nursing 2013; 876563.

21. Ghalandarpoorattar SM, Kaviani A, Asghari F. Medical error disclosure: the gap between attitude and practice. Postgrad Med J. 2012; 88:130-33.

22. Edmonds EC, Delano-Wood L, Jak AJ, et al. Missed mild cognitive impairment: High false-negative error rate based on conventional diagnostic criteria. J Alzheimers Dis. 2016; 52:1-7.

23. T.C. Sağlık Bakanlığı. Hasta Hakları Yönetmeliğinde Değişiklik Yapılmasına Dair Yönetmelik. Resmi Gazete, 08.05.2014; Sayı: 28994, Ulaşılabileceği adres: http://www.resmigazete.gov.tr/eskiler/2014/05/201 40508-3.htm 